\title{
Pengolahan Tanaman Singkong Menjadi Produk Es Krim Untuk Masyarakat Desa Kepek Kecamatan Saptosari Kabupaten Gunungkidul
}

\author{
Hadian, S.S. ${ }^{1}$, Jasmine, L.J. ${ }^{2}$, Wijaya, I.R. ${ }^{3}$, Krisna, D. ${ }^{4}$, Purba, H.A. ${ }^{5}$, Sinaga, C.E.D. ${ }^{6}$, Bella, M.A.D.C. ${ }^{7}$, Tarais, Y. ${ }^{8}$, Juliyanti, A. ${ }^{9}$, Amri, \\ K. ${ }^{10}$, Kristiawan, Y.B. ${ }^{11}$ \\ Universitas Atma Jaya Yogyakarta, Jalan Babarsari no. 44, Janti, Caturtunggal, Kec. Depok, Kabupaten Sleman, Daerah Istimewa \\ Yogyakarta 55281 \\ Email: benny.kristiawan@uajy.ac.id
}

Received: December $6^{\text {th }} 2020$; Revised: -; Accepted for Publication November $8^{\text {th }}$ 2021; Published: November $8^{\text {th }} 2021$

\begin{abstract}
Cassava or cassava is one of the largest food sources in Indonesia. Cassava is an alternative food that is rich in carbohydrates. In Kepek Village, Saptosari District, there are many crops produced from agriculture, namely rice, corn, cassava, peanuts, and soybeans. This journal will discuss the process of making ice cream with cassava-based ingredients, as well as a discussion of the mapping of village potentials owned by Kepek Village, Saptosari District. The method of making cassava ice cream is by utilizing the harvest products owned by Kepek Village, Saptosari District, by peeling and washing cassava. Then do soaking in water for 24 hours. Combine water, coconut milk, cornstarch, sugar, refined salt, sweetened condensed milk, and emulsifier in a saucepan. After that, the ice cream was put in the freezer for 24 hours with a temperature parameter of $4^{\circ} \mathrm{C}$. The results of the development of making ice cream using cassava as a base ingredient can find out another effective and interesting process regarding the utilization of agricultural products, namely cassava.
\end{abstract}

Keywords - cassava, cassava ice cream, village potential, Kepek Village, Saptosari District.

\begin{abstract}
Abstrak - Singkong atau ubi kayu merupakan salah satu sumber pangan terbesar di Indonesia. Singkong menjadi bahan pangan alternatif yang kaya akan karbohidrat. Pada Desa Kepek, Kecamatan Saptosari terdapat banyak hasil bumi yang dihasilkan dari pertanian yaitu padi, jagung, ketela pohon, kacang tanah, dan kedelai. Pada jurnal ini akan dibahas mengenai proses pembuatan es krim dengan bahan dasar singkong, serta pembahasan tentang pemetaan potensi desa yang dimiliki Desa Kepek, Kecamatan Saptosari. Metode pembuatan es krim singkong yaitu dengan memanfaatkan produksi hasil panen yang dimiliki oleh Desa Kepek, Kecamatan Saptosari, dengan cara singkong dikupas dan dicuci. Kemudian dilakukan perendaman dalam air selama 24 jam. Campurkan air, santan kelapa, tepung maizena, gula pasir, garam halus, susu kental manis, dan pengemulsi ke dalam panci. Setelah itu es krim dimasukkan ke dalam freezer selama 24 jam dengan parameter suhu $4^{\circ} \mathrm{C}$. Hasil dari pengembangan pembuatan es krim menggunakan bahan dasar singkong dapat mengetahui proses efektif dan menarik lain tentang pemanfaatan hasil bumi yaitu singkong.
\end{abstract}

Kata Kunci- singkong, es krim singkong, potensi desa, Desa Kepek, Kecamatan Saptosari.

\section{PENDAHULUAN}

Singkong atau yang biasa disebut ubi kayu, merupakan salah satu tanaman pangan terbesar ke-3 di Indonesia setelah padi serta jagung, yang sekaligus menjadi sumber kalori pangan termurah, dan bahannya banyak tersedia [1]. Singkong merupakan salah satu bahan pangan alternatif yang kaya akan karbohidrat, yang dapat berpotensi untuk mengatasi permasalahan ketergantungan impor gandum untuk pembuatan tepung terigu. Singkong memiliki beberapa keunggulan, diantaranya seperti kadar gizi makro (kecuali protein) serta mikro tinggi, di dalam usus dan lambung dapat berpotensi berperan sebagai prebiotik, serta merupakan tanaman pangan bersumber kalori potensial di wilayah yang didominasi oleh iklim kering [2]. Komponen kimia serta gizi dari singkong dibedakan menjadi 2, yakni dari bagian kulit dan bagian dagingnya. Komponen kimia dan gizi dari daging singkong dalam $100 \mathrm{~g}$ adalah protein $1 \mathrm{~g}$, kalori $154 \mathrm{~g}$, karbohidrat 36,8 g, dan lemak 0,1 g [3].

Singkong sebagai sumber energi yang kaya akan karbohidrat dapat diolah menjadi tepung singkong, yang dapat dimanfaatkan dalam pembuatan tepung campuran dengan tepung terigu. Hal ini dikarenakan tepung singkong mempunyai warna, tekstur, serta aroma yang menyerupai dengan tepung terigu, sehingga tepung campuran tersebut nantinya dapat digunakan dalam pembuatan roti, kue, mie, dan produk makanan ringan lain. Dengan berkembangnya teknik pengolahan tepung singkong menjadi berbagai makanan, diharapkan tepung singkong ini dapat digunakan sebagai bahan baku untuk menunjang industri pengolahan pangan. Selain itu, pengolahan singkong menjadi tepung ini diharapkan akan mempunyai nilai ekonomis yang tinggi, serta dapat digunakan untuk menunjang diversifikasi pangan. Hal ini dikarenakan selama ini ubi kayu umumnya hanya diolah sebagai gaplek, tepung tapioka, ataupun dibuat menjadi cemilan [2].

Pengolahan dengan bahan dasar singkong tentu sangat beragam. Tidak hanya dapat diolah menjadi tepung atau cemilan. Salah satu hasil pengolahan yang banyak diminati masyarakat adalah es krim. Es krim merupakan sebuah makanan beku yang dibuat dari produk susu seperti krim atau sejenisnya yang kemudian digabungkan dengan perasa dan pemanis buatan ataupun alami. Campuran ini akan didinginkan dengan mengaduk sambil mengurangi suhunya untuk mencegah pembentukan kristal es besar [4]. Es krim dengan bahan dasar singkong juga memiliki banyak sekali manfaat. Manfaat yang dimiliki ialah es krim dengan bahan dasar singkong kaya akan vitamin $\mathrm{K}$ yang berfungsi untuk menjaga kekuatan tulang sehingga dapat mencegah osteoporosis. Selain itu, terdapat kandungan vitamin lain yaitu vitamin B komplek dan kelompok vitamin seperti folates, thiamin, piridoksin (vitamin B-6), riboflavin dan asam pantotenat. Tidak hanya itu, es krim dengan bahan dasar 
Pengolahan Tanaman Singkong Menjadi Produk Es Krim Untuk Masyarakat Desa Kepek Kecamatan Saptosari Kabupaten Gunungkidul

singkong mempunyai kandungan kalium yang cukup tinggi yang bermanfaat sebagai pembentukan sel tubuh dan mengatur tekanan darah. Ditambah lagi, es krim singkong juga dapat menurunkan kadar kolesterol jahat dalam darah sehingga dapat menurunkan risiko penyakit jantung, stroke dan kanker usus besar. Sehingga, dengan adanya inovasi pengolahan es krim singkong dapat membuat masyarakat yang tidak menyukai singkong dapat tertarik untuk mencoba produk olahan es krim singkong yang kaya akan vitamin [5].

Untuk itu, tujuan dilakukannya pengabdian ini adalah membantu masyarakat dalam memanfaatkan hasil panen yang melimpah di Desa Kepek, Kecamatan Saptosari dengan dilakukan proses pengolahan hasil panen Singkong yang dapat berpotensi digunakan sebagai bahan pembuatan es krim. Selain itu, Desa Kepek, Kecamatan Saptosari memiliki potensi yang dapat dimanfaatkan bagi masyarakat. Potensi desa adalah segenap sumber daya alam dan sumber daya manusia yang dimiliki desa sebagai modal dasar yang perlu dikelola dan dikembangkan bagi kelangsungan dan perkembangan desa [6]. Salah satu potensi desa yang dimiliki oleh Desa Kepek adalah dari hasil pertanian. Dengan luas area panen untuk tanaman padi seluas 454 hektar dapat menghasilkan hasil panen dengan jumah produksi sebesar 1.916,78 ton. Terutama, lahan seluas 665 hektar di Desa Kepek digunakan untuk kegiatan pertanian tumbuhan jenis ketela pohon, dengan jumlah produksi sejumlah 10.001,60 ton [7]. Tentu merupakan hasil panen yang cukup melimpah. Sehingga melalui kegiatan yang dilakukan diharapkan dapat membantu masyarakat terutama di Desa Kepek, Kecamatan Saptosari agar dapat dijadikan sebagai inovasi untuk membuat home industri yang akan menambah ekonomi masyarakat, selain itu dapat digunakan untuk membuka lapangan pekerjaan baru dan dapat digunakan untuk diversifikasi pangan.

\section{Metode PenGabdian}

\section{A. Bahan Penelitian}

Bahan penelitian yang digunakan dalam penelitian ini adalah singkong yang merupakan hasil panen di Desa Kepek, Kecamatan Saptosari. Selain itu dibutuhkan bahan-bahan seperti lemak susu dengan kandungan 10\%-16\%, milk solidsnot fat atau juga dikenal dengan serum solids dengan kandungan sebanyak 9\%-12\%, pemanis (dapat dikombinasi dari sukrosa dan pemanis) dengan kandungan sebesar $12 \%$ $16 \%$, stabilizer dan emulsifiers dengan kandungan $0,2 \%$ $0,5 \%$, serta diperlukan air yang berasal dari susu padat atau bahan lainnya sebesar 55\% - 64\%. Selain itu, diperlukan peralatan untuk menunjang pembuatan olahan es krim yaitu, pisau, ember besar, tampah, penumbuk makanan, panci dan yang terpenting adalah freezer.

\section{B. Tahapan Kerja}

Dalam pelaksanaan kegiatan pengabdian yaitu pengolahan es krim singkong, diperlukan beberapa langkah dalam pelaksaannya yaitu sebagai berikut :

\section{- Pembuatan tepung singkong}

Pembuatan tepung singkong dilakukan dengan singkong yang diperoleh dikupas kulitnya terlebih dahulu, kemudian dilakukan pencucian dengan air hingga bersih. Singkong yang telah dikupas kemudian direndam di dalam air selama 24 jam, kemudian diiris menjadi potongan kecil-kecil kurang lebih berukuran 1 - 2 mm [2]. Singkong yang sudah diiris kemudian dijemur dengan panas matahari (pagi hingga siang), kemudian hasil pengeringannya dihancurkan dengan bantuan penumbuk. Hasil penumbukan kemudian diayak, sehingga nanti diperoleh tepung singkong yang halus [8].

- Pencampuran bahan singkong dengan bahan lain

Bahan-bahan yang akan digunakan disiapkan dengan rasio bahan sebagai berikut; $500 \mathrm{ml}$ air, $200 \mathrm{ml}$ santan kelapa, $10 \mathrm{~g}$ tepung maizena, $100 \mathrm{~g}$ gula pasir, $5 \mathrm{~g}$ garam halus, $80 \mathrm{~g}$ susu kental manis, pengemulsi SP secukupnya, dan tepung singkong secukupnya [9]. Air, santan kelapa, tepung maizena, gula pasir, garam halus, susu kental manis, dan pengemulsi dicampurkan ke dalam panci, kemudian bahanbahan diaduk serta sambil dipanaskan hingga adonan bahan menjadi homogen dan mendidih. Adonan yang sudah mendidih dan homogen, adonan dibiarkan menjadi dingin terlebih dahulu [10].

\section{- Pengemasan dan pendinginan}

Adonan yang sudah dingin kemudian dibagikan secara merata ke dalam kemasan plastik, kemudian dimasukkan ke dalam freezer serta penambahan dengan es batu. Es krim dalam kemasan kemudian disimpan selama 24 jam dengan suhu $4^{\circ} \mathrm{C}$, untuk memastikan es krim yang dibuat sudah mengeras dengan sempurna. Es krim yang yang sudah didinginkan kemudian dapat dipasarkan sesuai dengan kebutuhan masyarakat [10].

Berikut merupakan bagan cara kerja pengolahan es krim :

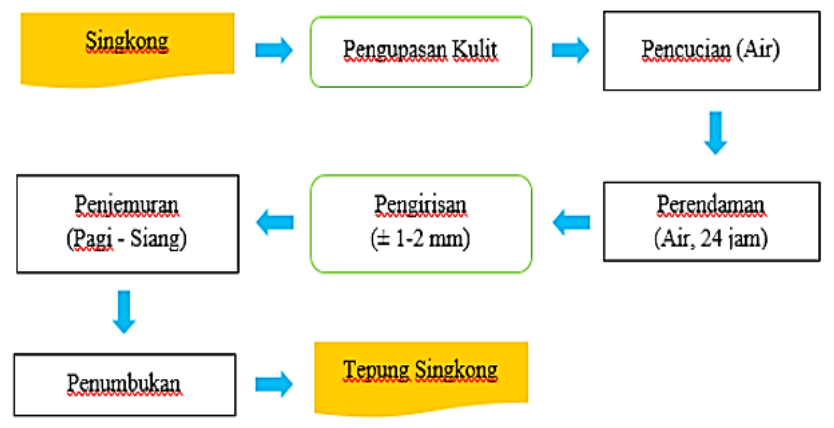

Gambar 2.1 Diagram pembuatan tepung singkong 


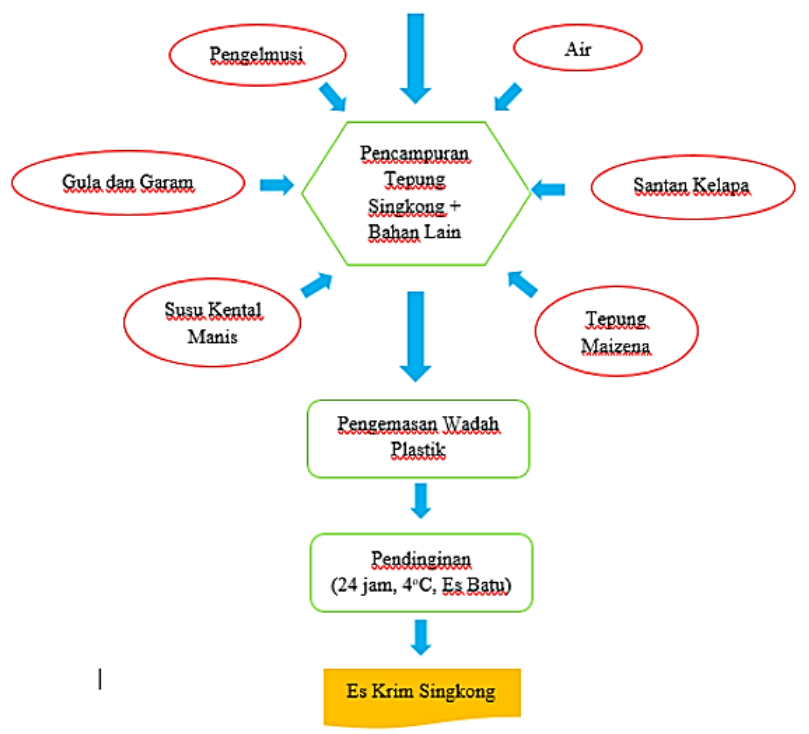

Gambar 2.2 Diagram pembuatan es krim singkong

\section{HASIL DAN PEMBAHAAN}

Penyuluhan dan cara untuk membuat olahan es krim dengan bahan dasar singkong dilakukan sesuai dengan potensi desa yang dimiliki oleh masyarakat di Desa Kepek, Kecamatan Saptosari. Serta, penyuluhan ini telah dilaksanakan oleh kelompok kkn 34 melalui pembuatan video serta bentuk buku saku yang akan dibagikan kepada masyarakat agar dapat dipahami dan digunakan sebagai panduan. Penyuluhan cara membuat olahan es krim dengan bahan dasar singkong ini bertujuan untuk membuat dan mengetahui inovasi yang dapat dihasilkan dari olahan singkong dengan memanfaatkan hasil pertanian Desa Kepek yang kaya akan hasil panennya. Selain itu, hasil olahan es krim dapat menarik minat banyak orang dari berbagai golongan, sehingga masyarakat di Desa Kepek dapat menambah pendapatan yang dihasilkan dari olahan es krim singkong. Selain itu, dengan adanya olahan es krim singkong dapat menambah variasi olahan yang dihasilkan. Untuk itu pengolahan es krim singkong ini dapat menjadi salah satu solusi masyarakat ditengah sangat minimalnya lapangan kerja yang ada.

Pelaksanaan pengabdian dimulai dengan melakukan survei terhadap lokasi desa melalui website resmi yang dimiliki oleh Desa Kepek, Kecamatan Saptosari. Langkah ini dilakukan bertujuan untuk mengetahui potensi yang dimiliki desa serta kondisi tata letak desa. Desa Kepek memiliki banyak potensi desa yang beragam, salah satu yang diangkat untuk dijadikan pengabdian adalah sektor pertanian. Pemilihan sektor pertanian bertujuan agar hasil panen yang dihasilkan di desa dapat diolah menjadi olahan yang banyak disukai oleh masyarakat.

Pada tahap selanjutnya, setelah melakukan diskusi bersama dengan semua anggota kelompok dan pembimbing, maka dapat dirumuskan bahwa akan dilakukan pengolahan singkong yang merupakan salah satu hasil panen yang ada di Desa Kepek, Kecamatan Saptosari untuk dijadikan olahan dengan inovasi baru yaitu es krim singkong. Kegiatan ini dimulai dengan melakukan kandungan yang dimiliki singkong, manfaat yang dimiliki singkong, bagaimana proses pembuatan, serta manfaat yang dapat diperoleh oleh masyarakat sekitar Desa Kepek. Kemudian, selain materi yang disampaikan, kegiatan ini juga meliputi simulasi pelatihan yang dilakukan melalui video pembuatan es krim singkong. Selanjutnya dibutuhkan alat dan bahan pendukung agar tercapainya pengabdian yang dilakukan. Alat dan bahan tersebut ialah lemak susu dengan kandungan 10\%-16\%, milk solids-not fat atau juga dikenal dengan serum solids dengan kandungan sebanyak 9\%-12\%, pemanis (dapat dikombinasi dari sukrosa dan pemanis) dengan kandungan sebesar $12 \%$ $16 \%$, stabilizer dan emulsifiers dengan kandungan 0,2\%$0,5 \%$, serta diperlukan air yang berasal dari susu padat atau bahan lainnya sebesar 55\% - 64\%. Selain itu, diperlukan peralatan untuk menunjang pembuatan olahan es krim yaitu, pisau, ember besar, tampah, penumbuk makanan, panci dan yang terpenting adalah freezer disiapkan. Apabila semua bahan dan alat yang diperlukan sudah terpenuhi, proses pengolahan singkong menjadi es krim dapat dilakukan.

Dengan dilakukannya program pengabdian kepada masyarakat di Desa Kepek, Kecamatan Saptosari yaitu penyuluhan materi tentang inovasi pengolahan singkong menjadi es krim dapat meningkatkan pemahaman tentang pentingnya kandungan vitamin yang dimiliki singkong bagi tubuh. Kemudian dapat meningkatkan pemahaman masyarakat tentang pengolahan berbagai macam hasil pertanian desa terutama singkong, dengan inovasi tersebut maka akan sangat bermanfaat untuk kelangsungan hidup masyarakat kedepannya.

\section{KESIMPULAN}

Berdasarkan hasil penelitian yang dilakukan maka dapat ditarik kesimpulan sebagai berikut :

1. Kegiatan pengabdian mahasiswa secara daring telah dilakukan oleh kelompok 34.

2. Pengolahan hasil panen singkong menjadi es krim dapat memberikan manfaat yang sangat besar bagi masyarakat Desa Kepek, Kecamatan Saptosari yang awam tentang pengolahan variasi hasil panen.

3. Proses pengolahan singkong menjadi es krim efektif untuk dilakukan karena dapat diminati oleh banyak orang.

4. Es krim singkong yang dihasilkan dapat dikonsumsi dengan aman oleh setiap orang karena kandungan dari es krim singkong yang akan vitamin.

5. Pengolahan es krim dari bahan dasar singkong dapat dikembangkan dan dijadikan sumber mata pencaharian bagi masyarakat desa.

\section{UCAPAN TERIMAKASIH (HEADING 5)}

Ucapan terima kasih disampaikan kepada Universitas Atma Jaya Yogyakarta dalam menyelenggarakan KKN 78 hingga tercapainya kegiatan ini yang merupakan bagian dari program kerja kelompok. 
Pengolahan Tanaman Singkong Menjadi Produk Es Krim Untuk Masyarakat Desa Kepek Kecamatan Saptosari Kabupaten

\section{DAFTAR PUSTAKA}

A. Mustafa, "Analisis Proses Pembuatan Pati Ubi Kayu (Tapioka) Berbasis Neraca Massa," Agrointek, vol. 9, no. 2, p. 118, 2016, doi: 10.21107/agrointek.v9i2.2143.

S. W. Pade and H. Akuba, "Pemanfaatan Tepung Ubi Kayu sebagai Substitusi Tepung Terigu dalam Pembuatan Biskuit," J. Agritech Sci., vol. 2, no. 1, pp. 1-9, 2018.

[3] S. Putri and W. Hersoelistyorini, "Kajian Kadar Protein, Serat, Hcn, Dan Sifat Organoleptik Prol Tape Singkong Dengan Substitusi Tape Kulit Singkong,” J. Pangan dan Gizi, vol. 3, no. 6, p. 115941, 2012.

A. Rozi, "Pengaruh Penggunaan Emulsifier Dan Kecepatan Pengadukan Yang Berbeda Terhadap Pembuatan Es Krim,” J. Chem. Inf. Model., vol. 53, no. 9, pp. 1689-1699, 2018.

Bargumono, "9 Umbi Utama Sebagai Pangan Alternatif Nasional," Agrica Ekstensia, p. 186, 2013.

[6] A. Soleh, "Strategi Pengembangan Potensi Desa," J. Sungkai, vol. 5, no. 1, pp. 35-52, 2017.

J. Parjanti and Kuncoro, Profile Desa Penyangga: Suaka Margasatwa Paliyan. Yogyakarta: KSDA Yogyakarta, 2018.

N. Hamidah, A. M Legowo, and S. Anwar, "Tepung ubi kayu (manihot esculenta) dan tepung tempe kedelai mempengaruhi pengembangan volume dan mutu gizi protein roti tawar," J. Gizi Indones. (The Indones. J. Nutr., vol. 4, no. 1, pp. 55-62, 2016, doi: 10.14710/jgi.4.1.55-62.

[9] Suyadi, Sunarto, and F. N. Rachman, "Rancang Bangun Mesin Pembuat Es Puter Dengan Pengaduk Dan Penggerak Motor Listrik,”J. Rekayasa Mesin, vol. 9, no. 2, pp. 41-46, 2014.
Jumiati, V. S. Johan, and Yusmarini, "Studi Pembuatan Es Krim Berbasis Santan Kelapa dan Bubur Ubi Jalar Ungu,” vol. 2, no. 2, pp. 1-12, 2015.

\section{PENUlis (HEADING 5)}

Stefani Septi Hadian, prodi Arsitektur, Fakultas Teknik Universitas Atma Jaya Yogyakarta

Laurentia Jovita Jasmine, prodi Akuntansi, Fakultas Bisnis dan Ekonomika, Universitas Atma Jaya Yogyakarta.

Iqbal Rizano Wijaya, prodi Manajemen, Fakultas Bisnis dan Ekonomika, Universitas Atma Jaya Yogyakarta

Dhany Krisna, prodi Biologi, Fakultas Teknobiologi Universitas Atma Jaya Yogyakarta

Hentika Angellia Purba, prodi Ekonomi Pembangunan, Fakultas Bisnis dan Ekonomika Universitas Atma Jaya Yogyakarta

Christin Eunike Debora Sinaga, prodi Manajemen, Fakultas Bisnis dan Ekonomika Universitas Atma Jaya Yogyakarta

Made Ayu Dinda Cintya Bella, prodi Hukum, Fakultas Hukum Universitas Atma Jaya Yogyakarta

Yuliani Tarais, prodi Hukum, Fakultas Hukum Universitas Atma Jaya Yogyakarta

Agnes Julistyani, prodi Arsitektur, Fakultas Teknik Universitas Atma Jaya Yogyakarta

Khaerul Amri, prodi Hukum, Fakultas Hukum Universitas Atma Jaya Yogyakarta

Yanuarius Benny Kristiawan, prodi Arsitektur, Fakultas Teknik Universitas Atma Jaya Yogyakarta 